\title{
Supporting Academic Growth of English Language Learners: Integrating Reading into STEM Curriculum
}

\author{
Saoussan A. Maarouf ${ }^{1, *}$ \\ ${ }^{1}$ College of Education and Health Professions, Columbus State University, Columbus, GA 31907, USA \\ *Correspondence: College of Education and Health Professions, Columbus State University, Columbus, GA 31907, \\ USA. E-mail: maarouf_saoussan@columbusstate.edu
}

Received: July 20, 2019

Accepted: August 10, 2019 Online Published: August 25, 2019

doi:10.5430/wje.v9n4p83

URL: https://doi.org/10.5430/wje.v9n4p83

\begin{abstract}
English Language Learners (ELLs) in the U.S. have recently received growing attention in educational research because of their struggle in academic performance, especially after the launch of the Common Core State Standards (CCSS) and assessments in 2009. Unfortunately, ELL students are required to take these standardized tests in English language regardless of their proficiency level in reading. Despite increased focus and resources of implementing STEM (Science, Technology, Engineering, and Math) curriculum in K-12 education, there is a strong evidence that ELL students do not attain commensurate performance when compared to their native English-speaking peers. The integration of Art into STEM disciplines has evolved STEM into STEAM. Lately, there has been much discussion in the educational field that the acronym STEAM should be further evolved into STREAM by integrating Reading. The purpose of this study is to investigate the efficacy of integrating STEM and Reading curriculum in K-12 education to reduce the achievement gap between ELL and non-ELL students. Practical classroom strategies for classroom teaching and instruction are discussed.
\end{abstract}

Keywords: English language learners, STEM reading integration, STREAM, content-based language learning

\section{Introduction}

According to a 2009 survey by the U.S. Department of Education (USDOE National Center for Education Statistics, 2009), about a quarter of students in the United States are immigrants or the children of immigrants. In 2013, the National Center for Education Statistics estimated that $10 \%$ of K-12 students in the U.S. can be classified as ELLs and predicted that the number will continue to increase to constitute $40 \%$ of the student population by 2030 (USDOE National Center for Education Statistics, 2015). A considerable percentage of these children, especially those with Spanish-speaking backgrounds, are falling behind in school. For instance, more than five million schoolchildren with Spanish-speaking backgrounds exhibit lower academic achievement in all subjects because they are still learning English (Maxwell, 2012). Student diversity across U.S. school districts is in the rise due to increasing numbers of ELLs (USDOE National Center for Education Statistics, 2015; Maxwell, 2012). In fact, ELLs represent a very diverse group in terms of knowledge to their native language, educational skills, access and affordability to early childhood programs, and immigration status. These students, unfortunately, have common negative trends in grade retention and educational outcomes, particularly in the area of reading (National Assessment of Educational Progress "NAEP", 2015; Turkan et al., 2014). Poor academic performance and grade retention are highly associated with higher school dropout rate (Hernandez, 2012). Research show that three policy reforms - increased attendance in school, enhanced instruction in English, and use of early intervention methods - could improve school achievement for ELLs, boost their economic well-being as adults, and increase their economic and social contributions to the American society (Short, 2017; Sparks, 2016).

There is an overwhelming evidence that ELL students are extremely challenged with the implementation of CCSS and consistently underperforming their English-speaking peers in all subjects, including STEM disciplines (Abedi \& Gándara, 2006; CCSS Initiative, 2017a; NAEP, 2015; Sullivan 2011). These findings promote the need of more research in this area and the support required for ELL students in STEM education. Research exploring the relationship between STEM subjects and reading skills is scant. However, researchers agree that the low scores of ELL students in math and science can be attributed to their limited ability in reading and comprehending the English 
language (Maxwell, 2012; Polat et al., 2016; Wright, 2006). Furthermore, STEM subjects normally include complex linguistical text and technical words that can impede the learning of ELL students (Huerta \& Spies, 2016). The inadequate reading capabilities of these students in STEM subjects will hinder their ability to generate inferences, interrupt their aptitude for robust information processing, and delay their cognitive development to achieve successful conceptual understanding about the domain.

Over the last decade, STEM employment grew at a much faster pace than non-STEM jobs; $24 \%$ versus $4 \%$ (Howard \& Ifenthaler, 2018; Langdon et al., 2011). Moreover, STEM employment is predicted to continue to grow much faster than other occupations for the foreseen future. Individuals in STEM fields enjoy $29 \%$ higher wages and $50 \%$ higher rate in obtaining a college degree compared to their counterparts in non-STEM fields (Howard \& Ifenthaler, 2018; Langdon et al., 2011). Taylor (2014) estimated that during the next three decades $90 \%$ of the U.S. labor force growth will come from new immigrants and their children and predicted that ELL students will constitute a significant portion of the work force. Hence, STEM education becomes a critical component in preparing ELL students with the skill level needed to make them prosper in a job market that is fueled by advancements in science and technology.

\section{Purpose - What Do We Want to Achieve by Integrating STREAM into ELLs' Education?}

School districts across the U.S. are seeing a rapid increase in enrollment of ELLs. According to the U.S. Department of Education (USDOE) and the National Institute of Child Health and Human Development (NICHD), 25\% of children above the age of five speak a language other than English at home and it is estimated that by the year 2030 about $45 \%$ of school students will speak English as a second language (USDOE \& NICHD, 2010). Many of the nation's school districts have experienced a demographic shift where half of the nation's teachers had at least one ELL in their classrooms (USDOE National Center for Education Statistics, 2015; USDOE \& NICHD, 2010). Compared to their monolingual peers, ELLs tend to perform lower in academic achievement and have negative outcomes in all educational subjects, particularly in STEM education. General education teachers sometimes are indecisive to refer ELLs to special education because they cannot determine if the issues of ELLs' difficulties with learning core STEM subjects are related to the acquisition of second language or a learning disability (Brown, 2007; Fuhui et al., 2014; Short, 2017). Many of these teachers are also confused regarding the appropriate time for referrals since school districts policies are not clear whether ELLs must acquire a minimal level of English proficiency before the referral process can start (Hakuta, 2013; Weinburgh, 2014).

Furthermore, teachers are faced with considerable challenges when dealing with the education of ELLs at a time when school districts are experiencing a serious increase in the population of these students. Politics, logistical shortcomings, identification procedures, infrastructures for data collection, and institutional capabilities are complicating the way we deal with the already complex needs of ELLs. Therefore, it is imperative that we make systematic efforts to take advantage of and, at the same time, critique the emergent empirical knowledge base on ELLs who are struggling to learn to read. Integrating STREAM into ELLs education can become a vehicle for adequately developing and engaging ELL students in STEM subjects. Adding reading to STEM curricula can provide the vital spark that is needed to assure a successful learning and advancement of ELL students in the fields of science, technology, engineering, and math. The integration of reading in the STEM subjects for ELLs must be done in an interdisciplinary and applied approach to ensure deeper learning across disciplines, improve comprehension and knowledge in content area, and motivate students to further develop their academic language skills.

\section{Strategies - Curriculum Models Integrating Reading into STEM Education and Their Benefits to ELLs}

In the last few decades, several researchers have asserted that reading skills of academic language are key factors to the success of ELL students in the math and science education (Abedi, 2002; Kieffer, 2008; Minicucci, 1996; Short, 2017; Tong et al., 2014). Many school districts in the United States have implemented scripted literacy programs that use a great deal of fluency and phonics in early education to accommodate ELLs in their classrooms (Ajayi, 2005; Herrera, 2010; Lesaux et al., 2014). However, the research is still meager at best when it comes to integrating reading into STEM subjects as a mean to improve ELL students' achievement in such subjects. This gap in research necessitates developing effective strategies to address the chronic achievement disparities between ELLs and their native English-speaking peers in STEM subjects.

When studying ELLs, the children's educational environment, cultural background, and language experiences should be considered. Teachers should learn more about children's language experiences at the time of school entry, since 
findings from studies related to ELLs in non-school settings may not apply to outcomes associated with changes in the language environment after school entry. Therefore, the prediction of children's outcomes may differ depending on whether they were exposed to two languages from birth or they were exposed to their parents' native language at home and English at the time of school entry. Moreover, the emphasis on instruction strategies and observing progress would likely impact student outcomes, more specifically ELLs who historically did not perform well on measures of student achievement.

The author of this study conducted a systematic review analysis by examining the volume and current state of empirical research in education literature that addressed integrating reading into the math and science education of ELL students in U.S. public schools. The author limited the results to only peer-reviewed articles during the last three decades, between 1988 and 2018. Two web-based search engines were used: GALILEO, an online library search system, and Google Scholar search engine. Table 1 summarizes the author's findings.

Table 1. Strategies Recommended by Researchers to Integrate Reading into Math and Science Subjects

\begin{tabular}{|c|c|c|c|c|c|c|}
\hline Strategy & Definition & Benefits & Challenges & Best Practices & $\begin{array}{c}\text { Assessment and } \\
\text { Effectiveness }\end{array}$ & $\begin{array}{c}\text { Relevant } \\
\text { Publications }\end{array}$ \\
\hline 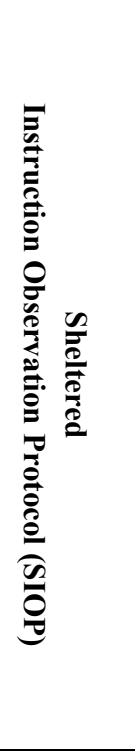 & $\begin{array}{l}\text { - Arguably, one } \\
\text { of the best } \\
\text { models for } \\
\text { working with } \\
\text { ELLs } \\
\text { - Teaching } \\
\text { content } \\
\text { subjects while } \\
\text { promoting } \\
\text { English } \\
\text { language } \\
\text { development } \\
\text { - Consists of } 8 \\
\text { components } \\
\text { along with } 30 \\
\text { features }\end{array}$ & $\begin{array}{l}\text { - Cooperative } \\
\text { learning } \\
\text { - Use of visuals } \\
\text { and } \\
\text { demonstrations } \\
\text { - Targeted } \\
\text { vocabulary } \\
\text { development } \\
\text { - Language-inten } \\
\text { sive instruction }\end{array}$ & $\begin{array}{l}\text { - Professional } \\
\text { development to } \\
\text { enhance } \\
\text { content-area } \\
\text { teachers } \\
\text { - Logistic } \\
\text { constraints may } \\
\text { limit the } \\
\text { availability of } \\
\text { time and } \\
\text { resources to } \\
\text { support SIOP }\end{array}$ & $\begin{array}{l}\text { - Six-step process } \\
\text { developed by } \\
\text { Marzano and } \\
\text { Pickering (2005) } \\
\text { - Three Tier } \\
\text { Model } \\
\text { developed by } \\
\text { Beck et. al } \\
\text { (2002) } \\
\text { - Explicit } \\
\text { Instruction } \\
\text { Approaches } \\
\text { developed by } \\
\text { Zwiers (2008) }\end{array}$ & $\begin{array}{l}\text { - Professional } \\
\text { development } \\
\text { to teachers of } \\
\text { ELLs } \\
\text { - Measuring } \\
\text { teacher } \\
\text { effectiveness } \\
\text { - Students gains } \\
\text { in content } \\
\text { areas and } \\
\text { English }\end{array}$ & $\begin{array}{l}\text { - Guarino et al. } \\
(2001) \\
\text {-Settlage et al. } \\
(2005) \\
\text { •Hansen-Thoma } \\
\text { s (2008) } \\
\text { - Batt (2010) } \\
\text { - Center for } \\
\text { Applied } \\
\text { Linguistics } \\
\text { (2011) } \\
\text { - Szpara (2017) }\end{array}$ \\
\hline
\end{tabular}




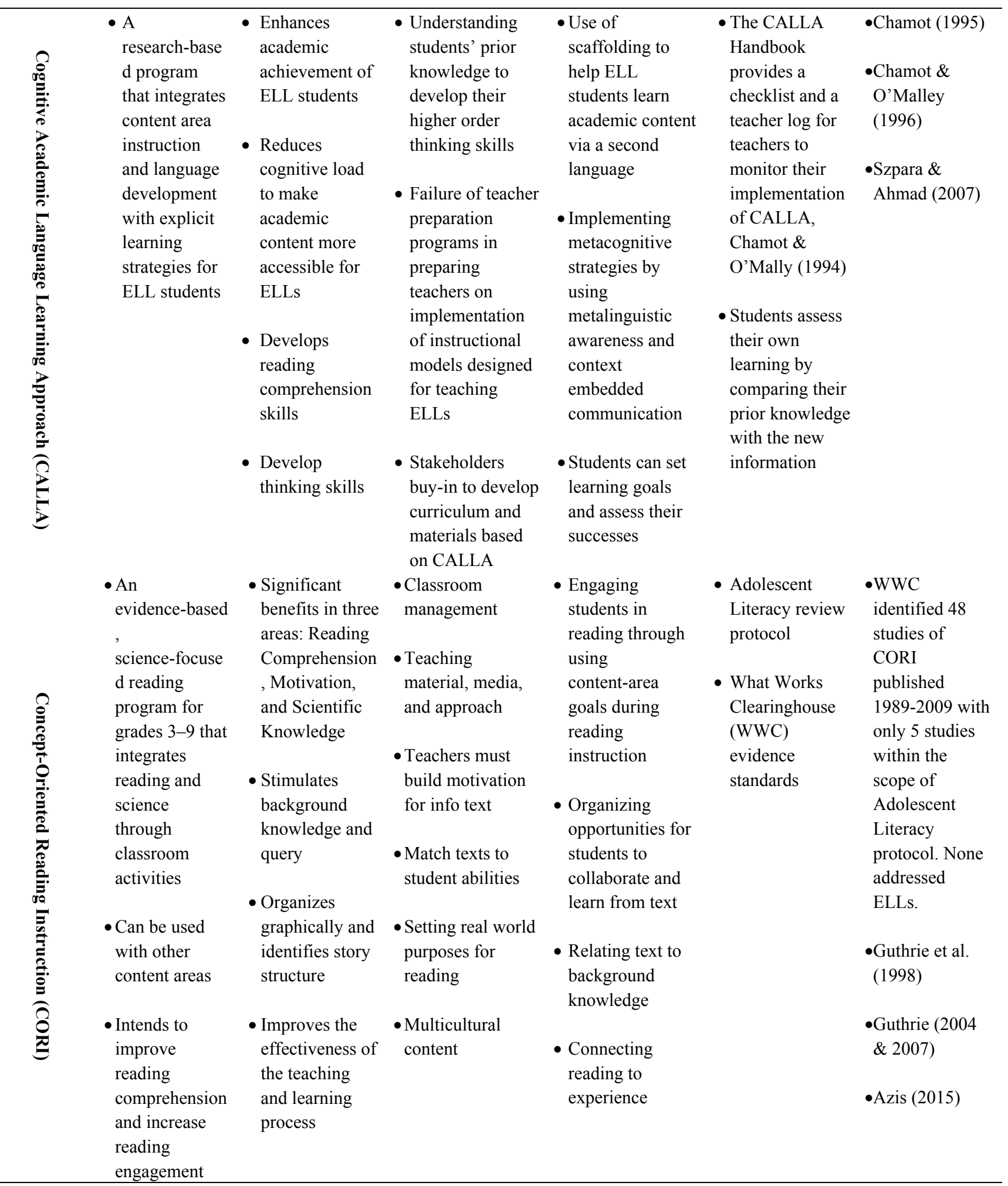




\begin{tabular}{|c|c|c|c|c|c|c|}
\hline 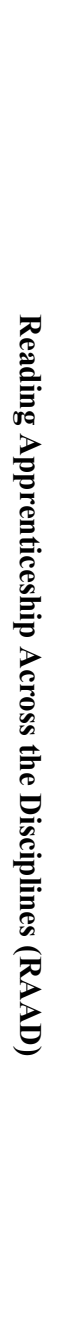 & $\begin{array}{l}\text { - Created by } \\
\text { WestEd } \\
\text { through a U.S. } \\
\text { Department of } \\
\text { Education } \\
\text { grant } \\
\text { (2015-2018) } \\
\text { - Uses explicit } \\
\text { instruction } \\
\text { and } \\
\text { explanation of } \\
\text { textual } \\
\text { meaning with } \\
\text { content } \\
\text { subjects' } \\
\text { objectives to } \\
\text { improve } \\
\text { language } \\
\text { proficiencies } \\
\text { and academic } \\
\text { success } \\
\text { - Promotes a } \\
\text { 4-dimensional } \\
\text { approach to } \\
\text { teaching and } \\
\text { learning: } \\
\text { personal, } \\
\text { social, } \\
\text { cognitive, and } \\
\text { knowledge }\end{array}$ & $\begin{array}{l}\text { - Improves } \\
\text { students' } \\
\text { knowledge, } \\
\text { strategies, and } \\
\text { confidence to } \\
\text { become more } \\
\text { - effective } \\
\text { readers } \\
\text { - A powerful } \\
\text { framework for } \\
\text { literacy } \\
\text { development } \\
\text { across all } \\
\text { subject areas } \\
\text { - Students build } \\
\text { skills for a } \\
\text { better } \\
\text { understanding } \\
\text { of complex, } \\
\text { subject-specific } \\
\text { texts }\end{array}$ & $\begin{array}{l}\text { - Teacher buy-in } \\
\text { and ownership are } \\
\text { key in } \\
\text { implementing } \\
\text { essential } \\
\text { instructional } \\
\text { change } \\
\text { - Sustainability and } \\
\text { amplifying the } \\
\text { extent to which } \\
\text { teachers report } \\
\text { implementing } \\
\text { RAAD practices }\end{array}$ & $\begin{array}{l}\text {-Teachers and } \\
\text { students work in } \\
\text { harmony and } \\
\text { reflect on mental } \\
\text { processes to } \\
\text { understand texts } \\
\text {-Building } \\
\text { students' } \\
\text { confidence to } \\
\text { become more } \\
\text { strategic and } \\
\text { independent } \\
\text { readers } \\
\text { - Supporting } \\
\text { students' } \\
\text { discovery, } \\
\text { understanding of } \\
\text { various } \\
\text { disciplinary texts } \\
\text { and genres } \\
\text { • Guiding student } \\
\text { to enquire, } \\
\text { explore, and } \\
\text { enhance their } \\
\text { reading skills }\end{array}$ & $\begin{array}{l}\text {-State } \\
\text { Standardized } \\
\text { Assessments } \\
\text { •Degrees of } \\
\text { Reading Power } \\
\text { (DRP) } \\
\text { •Metacognitive } \\
\text { Awareness of } \\
\text { Reading } \\
\text { Strategies } \\
\text { Inventory }\end{array}$ & $\begin{array}{l}\text {-WestEd (2004) } \\
\text {-Mehdian } \\
\text { (2009) } \\
\text {-WestEd (2016) }\end{array}$ \\
\hline
\end{tabular}




\begin{tabular}{|c|c|c|c|c|c|c|}
\hline 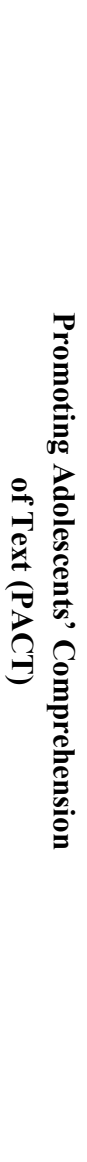 & $\begin{array}{l}\text {-A } \\
\text { research-based } \\
\text { approach to } \\
\text { improve } \\
\text { teachers' } \\
\text { instructional } \\
\text { methods for } \\
\text { promoting text } \\
\text { comprehension } \\
\text {-Consists of } \\
\text { four research } \\
\text { strands: } \\
\text { Intervention } \\
\text { Design } \\
\text { Experiments, } \\
\text { Experimental } \\
\text { Cognitive } \\
\text { Studies, } \\
\text { Motivation } \\
\text { Studies, and } \\
\text { Reader } \\
\text { Performance } \\
\text { Studies }\end{array}$ & $\begin{array}{l}\text {-Improved } \\
\text { outcomes in } \\
\text { reading } \\
\text { comprehension, } \\
\text { content } \\
\text { attainment, and } \\
\text { sustained content } \\
\text { and vocabulary } \\
\text { knowledge at } \\
\text { multiple points } \\
\text { of assessments } \\
\text {-Instructional } \\
\text { practices are well } \\
\text { aligned with best } \\
\text { practices for } \\
\text { teaching ELLs } \\
\text { •With appropriate } \\
\text { modifications, } \\
\text { PACT can yield } \\
\text { positive } \\
\text { outcomes for } \\
\text { ELLs }\end{array}$ & $\begin{array}{l}\text { •Persuading } \\
\text { content-area } \\
\text { teachers to learn } \\
\text { and implement } \\
\text { new strategies for } \\
\text { building } \\
\text { background } \\
\text { knowledge, } \\
\text { teaching academic } \\
\text { vocabulary, and } \\
\text { fostering critical } \\
\text { reading and } \\
\text { knowledge } \\
\text { exploration } \\
\text { • School } \\
\text { implementation of } \\
\text { evidence-based } \\
\text { practices }\end{array}$ & $\begin{array}{l}\text {-Improve } \\
\text { cognitive } \\
\text { processes } \\
\text { associated with } \\
\text { reading } \\
\text { comprehension to } \\
\text { identify potential } \\
\text { targets for } \\
\text { intervention } \\
\text { •Engage and } \\
\text { motivate students } \\
\text { to enhance their } \\
\text { reading } \\
\text { comprehension } \\
\text { outcomes } \\
\text { - Integrate and } \\
\text { apply new } \\
\text { instructional } \\
\text { strategies to } \\
\text { develop and test } \\
\text { the efficacy of } \\
\text { interventions for } \\
\text { students with } \\
\text { reading } \\
\text { comprehension } \\
\text { difficulties }\end{array}$ & $\begin{array}{l}\text {-AIMSweb Maze } \\
\text { CBM Reading } \\
\text { Comprehension } \\
\text {-ALI } \\
\text { (Adolescent } \\
\text { Literacy } \\
\text { Inventory) } \\
\text { •Content/backgro } \\
\text { und knowledge } \\
\text { assessment } \\
\text { •Researcher-Ada } \\
\text { pted Proximal } \\
\text { Comprehension } \\
\text { Measure } \\
\text { •PACT Battery } \\
\text { Descriptions } \\
\text { document }\end{array}$ & $\begin{array}{l}\text {-The Meadows } \\
\text { Center for } \\
\text { Preventing } \\
\text { Educational } \\
\text { Risk. (2013) } \\
\text {-Wanzek et al. } \\
\text { (2015) } \\
\text {-Vaughn et al. } \\
\text { (2017) }\end{array}$ \\
\hline
\end{tabular}




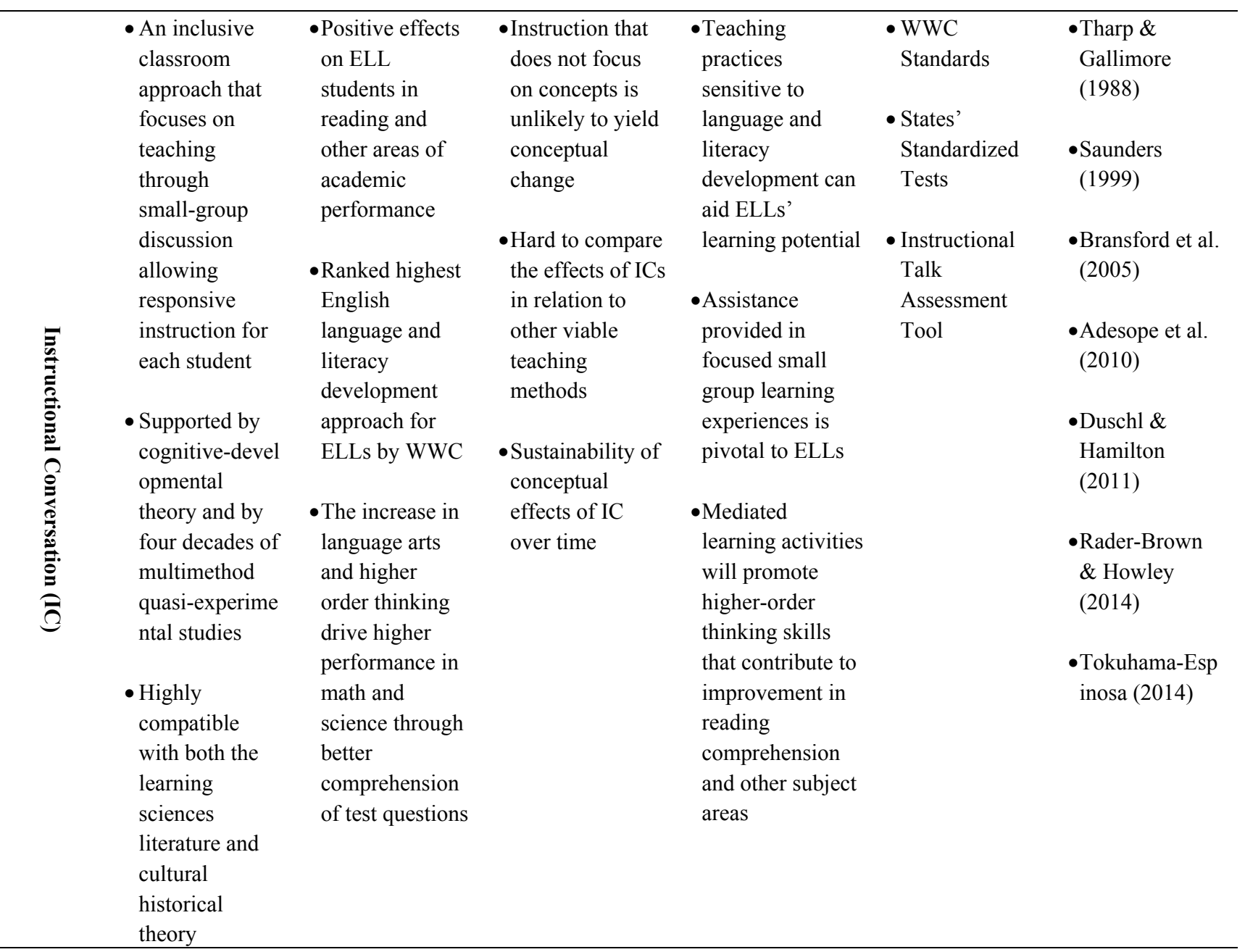




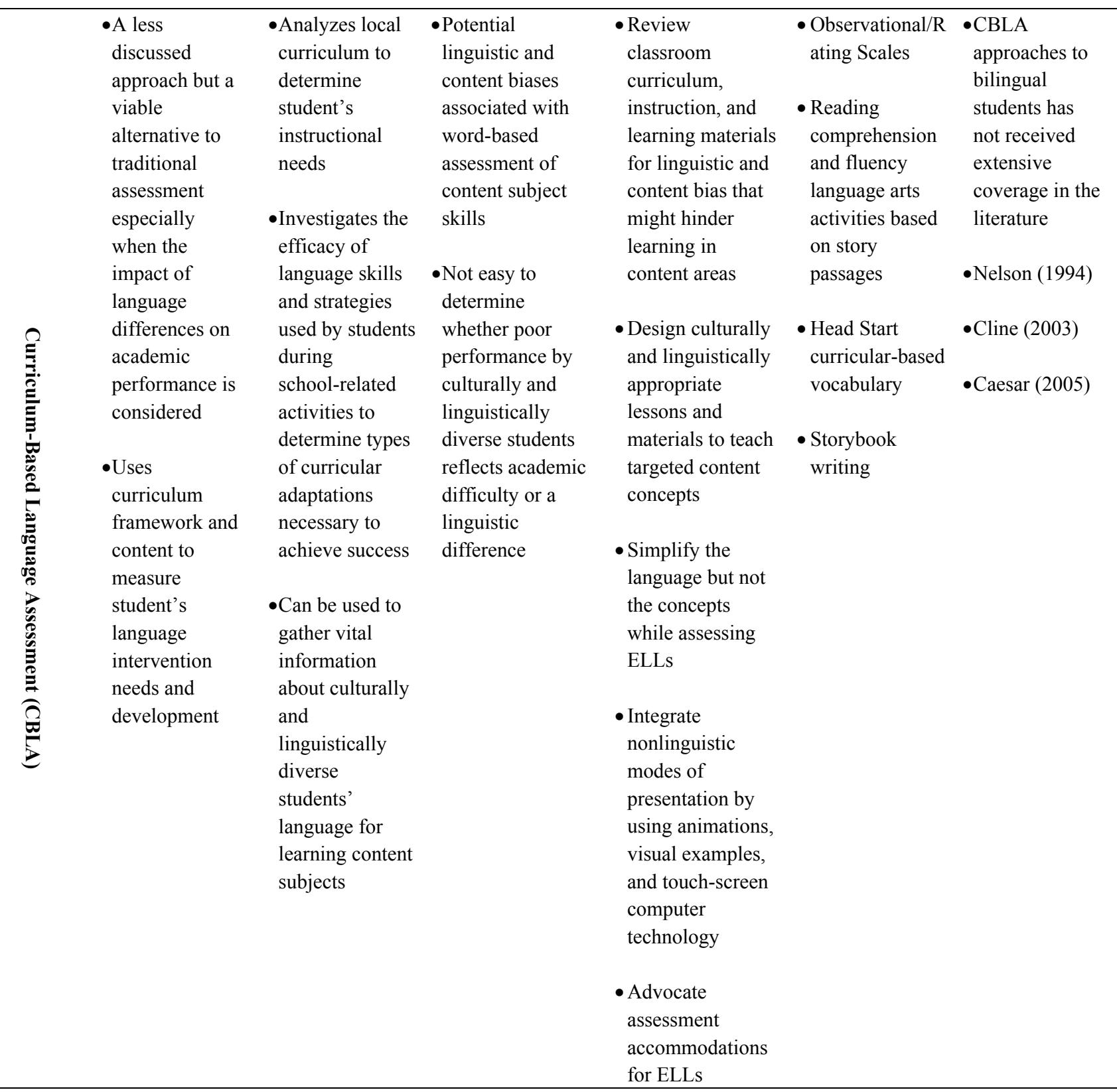




\begin{tabular}{|c|c|c|c|c|c|c|}
\hline 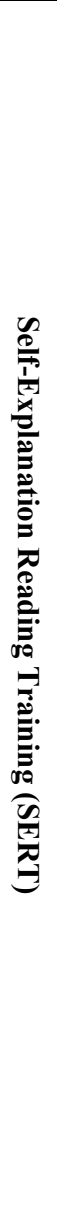 & $\begin{array}{l}\text { •Coalescing } \\
\text { self-explanatio } \\
\text { n with } \\
\text { instructions to } \\
\text { use reading } \\
\text { strategies while } \\
\text { explaining text } \\
\text { •Generating } \\
\text { inferences to } \\
\text { better } \\
\text { understand } \\
\text { low-cohesion } \\
\text { content subject } \\
\text { texts } \\
\text {-The automated } \\
\text { version of } \\
\text { SERT, known } \\
\text { as iSTART, } \\
\text { uses animated } \\
\text { agents to help } \\
\text { learners } \\
\text { practice how to } \\
\text { use } \\
\text { self-explanatio } \\
\text { n while reading } \\
\text { content subject } \\
\text { text }\end{array}$ & $\begin{array}{l}\text {-Designed to } \\
\text { improve } \\
\text { inference making } \\
\text { - Helps readers to } \\
\text { more effectively } \\
\text { explain text }\end{array}$ & $\begin{array}{l}\text {-Content subject } \\
\text { textbooks could } \\
\text { have cohesion } \\
\text { gaps, posing } \\
\text { additional hurdles } \\
\text { for ELL students } \\
\text { - Students with less } \\
\text { knowledge about } \\
\text { the domain } \\
\text { struggles with } \\
\text { poorly written text } \\
\text { - Readers who do } \\
\text { not possess } \\
\text { appropriate } \\
\text { linguistical skills } \\
\text { generally fail to } \\
\text { make the } \\
\text { inference and } \\
\text { understand the } \\
\text { concepts }\end{array}$ & $\begin{array}{l}\text { •Comprehension } \\
\text { monitoring } \\
\text {-Paraphrasing } \\
\text { •Elaboration } \\
\text {-Predictions } \\
\text {-Bridging }\end{array}$ & $\begin{array}{l}\text { - Prior knowledge } \\
\text { test } \\
\text { - Nelson Denny } \\
\text { reading skill test }\end{array}$ & $\begin{array}{l}\text { - Magliano et al. } \\
(2005) \\
\text { - O'Reilly et al. } \\
(2006) \\
\text { - Allen et al. } \\
(2015)\end{array}$ \\
\hline
\end{tabular}

As shown in Table 1, each of the pedagogical strategies listed in Table 1 has its own benefits and challenges. The common goals of these strategies are to: (1) provide proper assessment methods for ELL students, (2) implement a framework for their literacy development across all academic subjects, (3) improve teaching efficacies and drive students' competence in test performance using several disciplinary texts and genres, and (4) promote collaboration between teachers and their culturally and linguistically diverse ELL students. There is no "one size fits all" strategy. Each school should design and implement a strategy that will optimize the teaching processes of ELL students and improve their learnings. Aligning such strategies with the state's requirements and guidelines set by the federal government is paramount to improving teacher preparation and reducing achievement gap between ELL students and their English-proficient peers.

\section{Implications - How to Provide High Quality Teaching and Effective Learning Experiences Using STREAM}

One of the greatest challenges hindering the ability of ELL students to perform well in content subjects at the appropriate grade level is perhaps the lack of sufficient vocabulary development. Identifying ELL students who are at risk of failing STEM subjects and providing preventive measurements by integrating Reading instructions can have positive impact on their academic outcomes and learning. Hence, the author of this study recommends implementing the following four plan improvements in all classroom settings: 1) Categorization, 2) Pre-Referral and Referral Practices, 3) Assessment Practices and Eligibility Decisions, and 4) Instructional Interventions.

\subsection{Categorization}

Teachers should use a variety of tests to identify factors influencing the outcomes of language proficiency assessments of ELL students. The goal of such tests is to collect a comprehensive and accurate information about students' literacy levels in both English and their native language. Teachers should also determine proficiency of ELL students in STEM subjects and examine any relationship between acquiring a new language and students' outcome in STEM subjects. ELL students come from diverse linguistic and cultural backgrounds. Identifying 
students who struggle with literacy in English language and STEM subjects and who may or may not have learning disabilities is highly recommended. The No Child Left Behind Act (NCLB) of 2001 shifted the responsibility of educating ELL students from the federal government to individual states. Each state has developed its own assessment method to categorize and report the annual progress of ELL students in English language and academic subjects. As such, teachers should follow guidelines from their perspective states to implement a robust assessment program that takes into consideration ELL students' literacy in the English language and STEM subjects.

\subsection{Pre-referral and Referral Practices}

Before referring ELLs to special education, teachers should consider providing testing accommodations, testing modifications, and/or early interventions to students who consistently demonstrate signs of struggle in STEM subjects and reading. Teachers can develop appropriate pre-referral strategies within general education as part of a roadmap that may or may not lead to a formal referral process. This could incorporate consulting with experts in language acquisition in all phases of instructional design, adhering to a consistent referral policy, and conducting comprehensive academic assessment particularly when students appear to be delayed in acquiring their native language as well as English language. It is imperative that teachers consider socio-cultural and socio-economic factors, contextual features, school and program characteristics, and ELL students' learning opportunities during assessment, instructional, and referral phases of the education process.

\subsection{Assessment Practices and Eligibility Decisions}

Teachers should use creative methods when assessing students' strengths to determine the upper threshold of their potential in comprehending STEM subjects. They can observe ELL students in different settings as part of any assessment and pay more attention to cultural and sentimental considerations, particularly sources of potential conflict and motivation. Furthermore, teachers should give more attention to students' native language and to the role of language acquisition by utilizing the use of cognates whenever is possible. Assessing students' prior STEM knowledge in their first language as well as in English to determine predictors of their academic outcomes can go long way in providing appropriate strategies to bring these students to be on par with their English-speaking peers. Teachers should be cognizant that weak auditory processing skills to comprehend STEM subjects could relate to language acquisition rather than to a processing disorder or learning disabilities.

\subsection{Instructional Interventions}

There is a growing number of studies in the literature addressing effective instructional interventions strategies and models that blend content subject teaching and Reading (Henry et al., 2014; Short, 2017; Sparks, 2016; Tong et al., 2014). Instigating efficacious content and language-integrated instruction for ELL students should have positive impact on their academic outcomes. Combining STEM subjects teaching and reading comprehension with other English language development activities will help students develop a strong foundation in content subjects and promote their literacy in the English language (Carter et al., 2014; Hakuta; 2013; Turkan et al., 2014).

\section{Conclusion}

During the last few years, there has been a profound discussion in the field of education highlighting the benefits of integrating Reading to STEM subjects. Specifically, many researchers and organizations attest that there are significant benefits of Reading integration practices for ELL students (Dunn, 2017; Fuhui et al., 2014; Lorey, 2017; Messier \& Schroeder, 2014). However, the impact of such practices is not fully understood. The challenge of Reading and STEM integration in public schools include buy-in form various stakeholders and working with professionals from different backgrounds. In addition, STEM teachers do not think they are fully prepared or had the proper training to work with ELL students (Breiseth, 2016; Faltis, 2010; Weinburgh et al., 2014). Teacher preparation programs at colleges of education nationwide lagged behind the needs of providing proper training to their pre-service teachers. Most of the training that these teachers receive related to ELLs' education focuses heavily on decoding and fluency in language arts with an ill-advised expectation that comprehension will develop after ELL students are fluent word readers (Ajayi, 2005; Brown; 2007; Lesaux et al., 2014; Sparks, 2016).

Moreover, the implementation of CCSS has widened the academic gap between ELL students and their English-speaking peers. As a result, school districts have put more burden on teachers and held them accountable to ELL students' progress without providing them with the needed resources (CCSS Initiative, 2017b; Hakuta et al., 2013; Kieffer, 2008; Minicucci, 1996). Schools and educational researchers are now challenged by legislatures at the state and federal levels, parents, and other stakeholders to address the achievement gap and to bring forward creative strategies that can improve the academic progress of ELL students. The author of this study explored how Reading 
integration can be a vehicle to engage ELL students in a deeper STEM curriculum. The study articulated recommendations and implementation strategies that can be useful for content subject teachers. Further investigation on the impact of Reading on individual STEM subjects and the most effective strategy for integration is currently underway by the author.

\section{References}

Abedi, J. (2002). Standardized achievement tests and English language learners: Psychometric issues. Educational Assessment, 8(3), 234-257. https://doi.org/10.1207/S15326977EA0803_02

Abedi, J., \& Gándara, P. (2006). Performance of English language learners as a subgroup in large-scale assessment: Interaction of research and policy. Educational Measurement Issues and Practice, 25(4), 36-46. https://doi.org/10.1111/j.1745-3992.2006.00077.x

Adesope, O. O., Lavin, T., Thompson, T., \& Ungerleider, C. (2010). A systematic review and meta-analysis of the cognitive correlates of bilingualism. Review of Educational Research, 80(2), 207-245. https://doi.org/10.3102/0034654310368803

Ajayi, L. (2005). A sociocultural perspective: Language arts framework, vocabulary activities and English language learners in a second grade mixed classroom. Journal of Instructional Psychology, 32(3), 180-195.

Allen, L. K., McNamara, D. S., \& McCrudden, M. T. (2015). Change your mind: Investigating the effects of self-explanation in the resolution of misconceptions. In D. C. Noelle, R. Dale, A. S. Warlaumont, J. Yoshimi, T. Matlock, C. D. Jennings, \& P. Maglio (Eds.), Proceedings of the 37th Annual Cognitive Science Society Meeting (Cog Sci 2015). Pasadena, CA.

Azis, A. (2015). Teaching the use of concept-oriented reading instruction (CORI) to improve teaching and learning of reading narrative texts to grade VIII-B students. Journal English Language, 3(1), 1-8.

Batt, E. (2010). Cognitive coaching: A critical phase in professional development to implement sheltered instruction. Teaching and Teacher Education: An International Journal of Research and Studies, 26(4), 997-1005. https://doi.org/10.1016/j.tate.2009.10.042

Bransford, J., Barron, B., Pea, R., Meltzoff, A., Kuhl, P., Bell, P., . . . Sabelli, N. (2005). Foundations and Opportunities for an Interdisciplinary Science of Learning. In R. Sawyer (Ed.), The Cambridge Handbook of the Learning Sciences (Cambridge Handbooks in Psychology, pp. 19-34). Cambridge: Cambridge University Press. https://doi.org/10.1017/CBO9780511816833.003

Breiseth, L. (2016, July 12). Academic language and ELLs: What teachers need to know. Retrieved from http://www.colorincolorado.org/article/academic-language-and-ells-what-teachers-need-know

Brown, C. L. (2007). Supporting English language learners in content-reading. Reading Improvement, 44(1), 32-39.

Caesar, Lena G. (2005). Testing the tests: An investigation into the effectiveness of alternative assessment methods for bilingual language-impaired children. The Hilltop Review, 1(1), 41-51.

Carter, A., Cotten, S., Gibson, P., O'Neal, L., Simoni, Z., Stringer, K., et al. (2014). Integrating computing across the curriculum: Incorporating technology into STEM education. In Z. Yang, H. Hao Yang, D. Wu, \& S. Liu (Eds.), Transforming K-12 classrooms with digital technology (pp. 165-192). Hershey, PA: IGI Global. https://doi.org/10.4018/978-1-4666-4538-7.ch009

Center for Applied Linguistics (CAL). (2011). Helping educators work effectively with English language learners. Retrieved from http://www.cal.org/siop/resources/faqs.html

Chamot, A. (1995). Implementing the cognitive academic language learning approach CALLA in Arlington, Virginia. The Bilingual Research Journal, 19(3), 379-394. https://doi.org/10.1080/15235882.1995.10162680

Chamot, A., \& O’Malley, J. (1996). The cognitive academic language learning approach: A model for linguistically diverse classrooms. Elementary School Journal, 96(3), 259-273. https://doi.org/10.1086/461827

Cline, T. (2003). The assessment of special education needs for bilingual children. British Journal of Special Education, 25(4), 159-163. https://doi.org/10.1111/1467-8527.t01-1-00079

Common Core State Standards (CCSS) Initiative. (2017b). Application of Common Core State Standards for English language learners. Retrieved from http://www.corestandards.org/assets/application-for-english-learners.pdf

Dunn, J. (June, 2017). STREAM: Science, Technology, Reading, Engineering, Arts, and Math: Integrating STEAM 
and Reading. Paper presented at the ISTE conference, San Antonio, Texas.

Duschl, R. A., \& Hamilton, R. (2011). Learning science. In R. E. Mayer \& P. A. Alexander (Eds.), Handbook of research on learning and instruction (pp. 78-107). https://doi.org/10.4324/9781315736419

Faltis, C., Arias, M. B., \& Ramírez-Marín, F. (2010). Identifying relevant competencies for secondary teachers of English learners. Bilingual Research Journal, 33, 307-328. https://doi.org/10.1080/15235882.2010.529350

Fuhui, T., Irby, B., Lara-Alecio, R., \& Koch, J. (2014). Integrating literacy and science for English language learners: from learning-to-read to reading-to-learn. Journal of Educational Research, 107(5), 410-26. https://doi.org/10.1080/00220671.2013.833072

Guarino, A. J., Echevarria, J., Short, D., Schick, J. E., Forbes, S., \& Rueda, R. (2001). The sheltered instruction observation protocol: Reliability and validity assessment. Journal of Research Education, 11(1), 138-140.

Guthrie, J. T. (2004). Differentiating instruction for struggling readers within the CORI classroom. In J. T. Guthrie, A. Wigfield, \& K. C. Perencevich (Eds.), Motivating reading comprehension: Concept-Oriented Reading Instruction (pp. 173-193). Mahwah, NJ: Lawrence Erlbaum Associates.

Guthrie, J. T., McRae, A., \& Klauda, S. L. (2007). Contributions of concept oriented reading instruction to knowledge about interventions for motivations in reading. Educational Psychologist, 42, 237-250. https://doi.org/10.1080/00461520701621087

Guthrie, J. T., Schafer, W. D., Wang, Y. Y., \& Afflerback, P. (1998). Does concept-oriented reading instruction increase strategy use and conceptual learning from text?, Journal of Educational Psychology, 90(2), 261-278. https://doi.org/10.1037/0022-0663.90.2.261

Hakuta, K., Santos, M., \& Fang, Z. (2013). Challenges and Opportunities for Language Learning in the Context of the CCSS and the NGSS. Journal of Adolescent \& Adult Literacy, 56(6), 451-454. https://doi.org/10.1002/JAAL.164

Hansen-Thomas, H. (2008). Sheltered instruction: Best practices for ELLs in the mainstream. Kappa Delta P $i$ Record, 44(4), 165-169. https://doi.org/10.1080/00228958.2008.10516517

Henry, D., Nistor, N., \& Baltes, B. (2014). Examining the relationship between math scores and English language proficiency. Journal of Educational Research and Practice, 4(1), 11-29. https://doi.org/10.5590/JERAP.2014.04.1.02

Hernandez, D. J. (2012). Double jeopardy: How third-grade reading skills and poverty influence high school graduation. Baltimore, MD: The Annie E. Casey Foundation.

Herrera, S. G., Perez, D. R., \& Escamilla, K. (2010). Teaching reading to English language learners: Differentiated literacies. Boston, MA: Allyn \& Bacon.

Howard, N. R., \& Ifenthaler, D. (2018). Integrating STEM opportunities for young learners, Tech Know Learn, 23, 195-197. https://doi.org/10.1007/s10758-018-9364-1

Huerta, M., \& Spies, T. G. (2016). Science inquiry and writing for ELLs: A gateway for building understanding and academic language. Science Activities, 53(1), 24-32. http://dx.doi.org/10.1080/00368121.2015.1103693

Kieffer, M. J. (2008). Catching up or falling behind? Initial English proficiency, concentrated poverty, and the reading growth of language minority learners in the United States. Journal of Educational Psychology, 100, 851-868. https://doi.org/10.1037/0022-0663.100.4.851

Langdon, D., McKittrick, G., Beede, D., Beethika, K., \& Doms, M. (2011). STEM: Good jobs now and for the future. U.S. Department of Commerce; Economics and Statistics Administration. Retrieved from http://www.esa.doc.gov/sites/default/files/reports/documents/stemfinaljuly14.pdf

Lesaux, N. K., \& Kieffer, M. J. (2010). Exploring sources of reading comprehension difficulties among language minority learners and their classmates in early adolescence. American Educational Research Journal, 47, 596-632. https://doi.org/10.3102/0002831209355469

Lesaux, N. K., Kieffer, M. J., Kelley, J. G., \& Harris, J. R. (2014). Effects of academic vocabulary instruction for linguistically diverse adolescents: Evidence from a randomized field trial. American Educational Research Journal, 51, 1159-1194. https://doi.org/10.3102/0002831214532165

Lorey, A. (2017, March 16). Integrating Literacy into STEAM Lessons. Retrieved from https://thejournal.com/articles/2017/03/16/integrating-literacy-into-steam-lessons.aspx 
Magliano, J. P., Todaro, S., Millis, K. K., Wiemer-Hastings, K., Kim, H. J., \& McNamara, D. S. (2005). Changes in reading strategies as a function of reading training: A comparison of live and computerized training. Journal of Educational Computing Research, 32, 185-208. https://doi.org/10.2190/1LN8-7BQE-8TN0-M91L

Maxwell, L. A. (2012). Raising Latino achievement seen as 'Demographic Imperative'. Education Week, 31(34), 4-5.

McNamara, D. S. (2004). SERT: Self-explanation reading training. Discourse Processes, 38, 1-30. https://doi.org/10.1207/s15326950dp3801_1

Mehdian, N. (2009). Teacher's role in the Reading Apprenticeship framework: Aid by the side or sage by the stage. English Language Teaching, 2(1), 3-12. https://doi.org/10.5539/elt.v2n1p3

Messier, S., \& Schroeder, S. (2014, November 17). 6 elements of a successful iPad implementation. Retrieved from https://www.iste.org/explore/articleDetail?articleid=219\&category=Lead-the-way\&article=6-elements-of-a-suc cessful-iPad-implementation

Minicucci, C. (1996). Learning science and English: How school reform advances scientific learning for limited English proficient middle school students. Santa Cruz, CA: National Center for Research on Cultural Diversity and Second Language Learning.

National Assessment of Educational Progress (2015). 2015 National Mathematics \& Reading Assessment. Retrieved from http://www.nationsreportcard.gov/reading_math_2015/

Nelson, N. W. (1994). Curriculum-based language assessment and intervention across grades. In E. Wallach \& K. Butler (Eds.), Language learning disabilities in school-age children and adolescents (pp. 104-131). New York: Macmillan.

O’Reilly, T., Taylor, R. S., \& McNamara, D. S. (2006). Classroom based reading strategy training: Self-explanation vs. a reading control. In R. Sun \& N. Miyake (Eds.), Proceedings of the 28th Annual Conference of the Cognitive Science Society (pp. 1887-1892). Austin, TX: Cognitive Science Society.

Polat, N., Zarecky-Hodge, A., \& Schreiber, J. B. (2016), Academic growth trajectories of ELLs in NAEP data: The case of fourth- and eighth grade ELLs and non-ELLs on mathematics and reading tests. The Journal of Educational Research, 109(5), 541-553. https://doi.org/10.1080/00220671.2014.993461

Rader-Brown, L., \& Howley, A. (2014). Predictors of the instructional strategies that elementary school teachers use with English language learners. Teachers College Record, 116, 1-34.

Saunders, W. (1999). Improving literacy achievement for English learners in transitional bilingual programs. Educational Research and Evaluation, 5(4), 345-381. https://doi.org/10.1076/edre.5.4.345.6936

Short, D. J. (2017). How to Integrate content and language learning effectively for English language learners. Journal of Mathematics Science and Technology Education, 13(7b), 4237-4260. https://doi.org/10.12973/eurasia.2017.00806a

Sparks, S, D. (2016). Teaching English-learners: What does the research tell us? Education Week, 35(30), 3-6.

Settlage, J., Madsen, A., \& Rustad, K. (2005). Inquiry science, sheltered instruction, and English language learners: Conflicting pedagogies in highly diverse classrooms. Issues in Teacher Education, 14(1), 39-57.

Sullivan, A. L. (2011). Disproportionality in special education identification and placement of English language learners. Exceptional Children, 77, 317-334. https://doi.org/10.1177/001440291107700304

Szpara, M. (2017). Injustice for English language learners - Common Core raises academic standards without increasing supports: A descriptive case study of a Philadelphia teacher cohort. Literacy Practice \& Research, 43(1), 26-33.

Szpara, M., \& Ahmad, I. (2007). Supporting English-language learners in social studies class: Results from a study of high school teachers. Social Studies, 98(5), 189-196. https://doi.org/10.3200/TSSS.98.5.189-196

Taylor, P. (2014). The next America: boomers, millennials, and the looming generational showdown (1st ed.). New York: Public Affairs.

Tharp, R. G., \& Gallimore, R. (1988). Rousing minds to life: Teaching, learning, and schooling in social context. New York: Cambridge University Press.

The Meadows Center for Preventing Educational Risk. (2013). Sample lesson components for PACT Instruction Refined for English Language Learners. College of Education, The University of Texas at Austin, Austin, TX. 
Tokuhama-Espinosa, T. (2014). Making classrooms better: 50 practical applications of mind, brain, and education science: WW Norton \& Company.

Tong, F., Irby, B., Lara-Alecio, R., \& Koch, J. (2014). Integrating literacy and science for English language learners: From learning-to-read to reading-to-learn. The Journal of Educational Research 107(5), 410-426. https://doi.org/10.1080/00220671.2013.833072

Turkan, S., de Oliveira, L., Lee, O., \& Phelps, G. (2014). Proposing a knowledge base for teaching academic content to English language learners: Disciplinary linguistic knowledge. Teachers College Record, 116(4), 1-30.

U.S. Department of Education, National Center for Education Statistics. (2009). Status and trends in the education of Hispanics. Washington, DC.

U.S. Department of Education, National Center for Education Statistics (2015). English Language Learners in Public Schools. Washington, DC: The Common Core of Data (CCD).

U.S. Department of Education, \& National Institute of Child Health and Human Development. (2010). National symposium on learning disabilities in English language learners. Symposium summary. Washington, DC: U.S. Government Printing Office.

Vaughn, S., Martinez, L. R., Linan-Thompson, S., Reutebuch, C. K., Carlson, C. D., \& Francis, D. J. (2009). Enhancing social studies vocabulary and comprehension for seventh-grade English language learners: Findings from two experimental studies. Journal of Research on Educational Effectiveness, 2, 297-324. https://doi.org/10.1080/19345740903167018

Vaughn, S., Martinez, L.R., Wanzek, J., Roberts, G., Swanson, E., \& Fall, A. M. (2017). Improving content knowledge and comprehension for English language learners: Findings from a randomized control trial. Journal of Educational Psychology, 109(1), 22-34. https://doi.org/10.1037/edu0000069

Wanzek, J., Kent, S. C., Vaughn, S., Swanson, E. A., Roberts, G., \& Haynes, M. (2015). Implementing team-based learning in middle school social studies classes. The Journal of Educational Research, 108, 331-344. https://doi.org/10.1080/00220671.2014.893224

Weinburgh, M., Silva, C., Horak-Smith, C., Groulx, K., \& Nettles, J. (2014). The intersection of inquiry-based science and language: Preparing teachers for ELL classrooms. Journal of Science Teacher Education, 25(5), 519-541. https://doi.org/10.1007/s10972-014-9389-9

WestEd. (2004). 2001-2004: Reading Apprenticeship classroom study linking professional development for teachers to outcomes for students in diverse subject-area classrooms. San Francisco, CA: Author.

WestEd. (2016). Reading Apprenticeship Across the Disciplines SEED Grant: 2015-2018. San Francisco, CA: Author.

Wright, W. E. (2010). Foundations for Teaching English Language Learners: Research, Theory, Policy, and Practice. Philadelphia: Caslon Publishing. 